OPEN ACCESS

Manuscript ID:

ECO-2020-08043272

Volume: 8

Issue: 4

Month: September

Year: 2020

P-ISSN: 2319-961X

E-ISSN: 2582-0192

Received: 05.06.2020

Accepted: 28.07.2020

Published: 01.09.2020

Citation:

Gopalasundar, R. "The

Socio-Economic Conditions

of Women Agricultural

Labourers in Thanjavur

District of Tamil Nadu

in India." Shanlax

International Journal of

Economics, vol. 8, no. 4,

2020, pp. 54-58.

DOI:

https://doi.org/10.34293/

economics.v8i4.3272

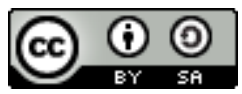

This work is licensed under a Creative Commons Attribution-ShareAlike 4.0 International License

\section{The Socio-Economic Conditions of Women Agricultural Labourers in Thanjavur District of Tamil Nadu in India}

\author{
R. Gopalasundar
}

Assistant Professor, PG Department and Research Centre in Economics

Saraswathi Narayanan College (A), Madurai, Tamilnadu, India

D https://orcid.org/0000-0002-7291-4405

\section{Abstract}

The seasonal nature of agriculture and low productivity reduce demand for female labor and as a result, forced idleness is higher among women than men. Women's productivity in agriculture also suffers from uneconomic holdings and subsistence nature of agriculture in which the family consumes the produce. Tasks performed by women are labor-intensive and mostly done by hand. This has reduced the work efficiency of women. Regardless of these variations, there is hardly any activity in agricultural production.

Keywords: Agriculture, Agricultural Labourers and Agricultural Production.

\section{Introduction}

The seasonal nature of agriculture and low productivity reduce demand for female labor and as a result, forced idleness is higher among women than men. Women's productivity in agriculture also suffers from uneconomic holdings and subsistence nature of agriculture in which the family consumes the produce. Tasks performed by women are labor-intensive and mostly done by hand. This has reduced the work efficiency of women. Regardless of these variations, there is hardly any activity in agricultural production.

Women in agriculture make up a substantial portion of the Indian rural population. Like men, they undertake various types of agricultural operations, including the allied fields, such as live-stock, forestry, plantations, fisheries, etc. broadly, they are engaged in these operations in their ways depending on the socio-economic status of their family and certain other regional factors. They work as (i) paid laborers, or (ii) cultivators-doing labor in their land as unpaid workers or (iii) managers of certain aspects of agricultural production by way of labor supervision, participating in post-harvesting processing, etc.

\section{Statement of the Problem}

The present study aims to probe into the work environment of the laborers in Thanjavur district. One characteristic feature of agricultural labor is that only men perform some jobs, while only women perform others, but both men and women do few jobs. It creates a disparity in wage rates between the male and female workers. It brings down the bargaining power of women workers and reduces them to the state of marginal, intermittent, or reserve labor, which is mostly unorganized. Discrimination within the labor market is the focus of the attention of this study. 
By discrimination within the market, it is implied that, workers who are distinguished by some characteristics such as sex, caste, status, etc. That do not affect their present capacity but are treated less favorably in a given job than others who have no greater capability but are not marked-off by the characteristics. Thus discrimination exists in a labor market when persons with differences in productivity are paid equal wages. The most important types of labor market discrimination are in wages, days of employment, and occupational characteristics. However, wage and employment discrimination are the outcomes of occupational discrimination. In the agricultural labor force, the participation of both men and women is not uncommon. However, there are important differences between the male and female workers in agriculture, like works done, rate of participation, wage rate, and income earned. Female workers do relatively less hard physical work; they are paid lesser wage rate, and are constrained by time to be shared between their responsibilities at home and out of it.

Further, in the agricultural labor households, women go to work to help men and to supplement their income, and they do work not paid for; the wage rates are to be imputed. Women manage to meet the scarcity of labor during the peak season of demand in agriculture and to find non-farm employment in the off-season. Thus, their annual income forms a significant share of their family income, but they have little say in spending it. The present study is also a modest attempt to find out the factors responsible for the existence of wage and discrimination in the agricultural labor market. It pays special attention to the problem of female labor at home and in the working place. Thus, gender discrimination in the agricultural labor market in an important area of focus taken up for scrutiny.

\section{Objectives}

1. To study the socio-economic characteristics of women agricultural labor households in the selected two taluks of Thanjavur District.

2. To understand the nature and extent of employment of women agricultural laborers in the selected two taluks of Thanjavur District.

3. To assess the extent of discrimination of women in employment and wage rate (operation-wise) and

4. To compare the minimum and actual wage; actual and expected wage.

\section{Hypotheses}

The hypotheses framed during the study are as follows

1. The participation of women in the agricultural labor force is not less than that of men, but the nature of work done by them differs from men.

2. Women are discriminated from men in employment and wage rate in doing similar activities on the farm.

3. The percentage of days of employed in a year in the case of agricultural and non-agricultural activities are lower in both the study taluks.

4. The minimum wage fixed by the Government is higher than the actual wage, and the expected wage is higher than the minimum wage in both the study taluks.

5. The percentage contribution of women to total family income is greater in the study taluks.

\section{Methodology}

Thanjavur district of Tamil Nadu was chosen for the study for several reasons. First, the researcher was familiar with and had easy access to most of the areas. That reduced cost of work and facilitated an in-depth analysis. Secondly, the district is primarily and agricultural district, with 76 percent of its population depending on farming either directly or indirectly for their livelihood. Nearly 30 percent of the total population are women agricultural laborers. Therefore, the selection of areas provided the scope for an intensive analysis of labor problems, especially women labor in agriculture. Lastly, several government-sponsored schemes were in operation, benefiting the farm sector. The availability of irrigation facilities enhances the scope for employment and high wages to the farm workers. Therefore the conditions of employment of labor vastly differ between irrigated and dry areas. Thanjavur district has very distinct areas, one irrigated by river Cauvery and another rainfed. This enabled the researcher to study the impact of irrigation on the employment of labor.

$$
\mathrm{X} 7=\text { Wage from non-agricultural activities }
$$




\section{Period of Study}

The data for the study related to the financial year 2018-2019 and actual field inquiries were conducted during the month from February 2019 to February 2020. The pilot survey was undertaken to ascertain the field problems and refine the important variables. The study has made use of statistical tools like correlation and multiple regressions. The regression models were computed to explain the total income of the women agricultural laborers in both the study taluks.

\section{Sample Design}

Thanjavur District consisted of 14 community development blocks (Panchayat unions) covering 900 revenue villages and ten taluks. The taluks were grouped into two distinct agro-climatic regions viz..

- Wet region Pattukkottai taluk receiving irrigation from river Cauvery and

- Dry farming region Orathanadu taluk depending largely on rainfall and ground water irrigation to a limited extent. In each region, one taluk was selected at random, and in each taluk, fiverevenue villages were selected. The sample taluks were Pattukkottai and Orathanadu. A discussion with officials of the Department of Agriculture, Government of Tamil Nadu indicated that the selected taluks are good representatives of the respective regions and justified their choice. In each village, 20 labor households were selected by simple random sampling method. Therefore, the ultimate sample consisted of 200 women labor households selected by a multistage stratified random sampling method.

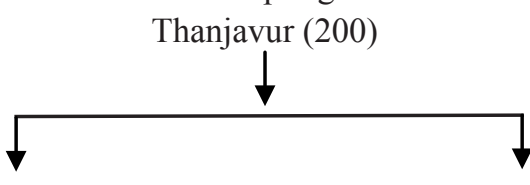

Pattukkottai

(100)

(i) Nattuchalai (20)

(iii) T.Maravakkadu (20)

(iv) Enathi (20)

(v) Pudukkottai Ulur (20) (ii) Parakkalakkottai (20)
Orathanadu (100)

(i) Eachankottai (20)

(ii) Kannukudi West (20)

(iii) Mela Ulur (20)

(iv) Neivasal South (20)

(v) Thondarampattu (20)

\section{Collection of Data}

All the workers in the labor households were covered by the study. As there were at least one male worker and a female worker in each of the sample households, there were more than 200 laborers to be studied. Primary data were collected by personal interview methods with the help of specially designed, pre-tested, and comprehensive questionnaires. The following information was collected from the women labor in agriculture.

\section{Tools of Analysis}

The study has made use of the statistical tools of analysis like averages, percentages, ratio, test of significance, ' $t$ ' test, correlation coefficient matrix, and multiple regressions. Earner Dependent Ratio was assessed by computing 'ratios', family size, annual income, savings, borrowings, expenditure, number of days employed in agricultural and nonagricultural activities and total wage of women laborers were employed by adopting 'averages,' to find out the percentage contribution of women to the total family income. Age of the women laborers, number of activities involved by both men and women laborers, and wage discrimination were calculated by using 'percentages.' And correlation coefficient matrix was applied to study the relationship among variables such as the number of days employed in agricultural activities, non-agricultural activities, family size, husband's income, women's wage from agriculture and non-agriculture, and women's total wage in both the study taluks.

To find out wage discrimination, the following formula is applied :

Wage Discrimination $(\mathrm{WD})=\frac{\begin{array}{c}\text { Male Wage MW } \\ \text { Female Wage FW }\end{array}}{\text { Female Wage FW }}$

The following regression model was computed to explain the total income of the family from all sources of the women agricultural labor households in both the study taluks.

$$
Y=f[x 1, x 2, x 3, x 4, x 5, x 6, x 7]
$$

Where,

$\mathrm{Y}=$ Total Income

$\mathrm{X} 1=$ Husband's Income

$\mathrm{X} 2$ = Days employed in non-agricultural activities by women agricultural labourers. 
$\mathrm{X} 3=$ Educational status

$\mathrm{X} 4=$ Family size

X5 $=$ Social Status

X6 $=$ Wage from agricultural activities

$\mathrm{X} 7=$ Wage from non-agricultural activities

\section{Findings}

Socio-economic characteristics of the women agricultural labor households:

a. Size of the family: It is found that the average size of the household in Pattukkottai is 4.7 and 4.6 in Orathanadu. But the overall average size of a family is found to be around five members.

b. Type of family: Out of 200 women agricultural labor households, 96.5 percent belong to a nuclear type of family, and the remaining 3.5 percent live in a joint family system in both the taluks.

c. Caste: The majority of the women agricultural laborers (86.5 percent) belong to scheduled caste, and the remaining 13.5 percent belong to backward community.

d. Religion: It is found that all the women's agricultural laborers belong to the Hindu religion, and none of them are Christians and Muslims.

e. Marital status: Regarding the marital status, all the women agricultural laborers are married and live with their husbands and child/children.

f. Type of house: The data revealed that most of the labors (85 percent) live in huts (one-room house), nine percent live in tiled houses, and six percent live in houses with concrete roofs.

g. Age: (Women agricultural laborers). The women's agricultural laborers are found in the age group ranging from 30 to 35 years (74 percent) in both the taluks.

h. Educational status: In both the taluks, 66 percent of them are illiterates, 23 percent had only primary education while 10.5 percent had secondary education, and very few ( 0.5 percent $)$ studied only up to higher secondary level.

\section{Conclusion}

Findings of results and conclusions drawn from them and discussed above have some important implications for policy and future research. Since this study covers only the sample representatives of Thanjavur district and two sample taluks, namely
Pattukkottai and Orathanadu, the generalization of results must be made with care. The policy implications of this study are given below.

Women laborers are employed generally in transplanting, weeding, winnowing, pluckers of seedlings, sowing, and harvesting. Women's wages, even in operations such as weeding and transplanting, for which they are particularly suited, are much lower than men's wages. The rational of the Equal Remuneration Act is to provide wages to women laborers on par with male laborers. It is clear that there is social injustice in the study area, and it has to be removed without delay. Many alternative ways are available to fight this injustice.

The enforcement of the Equal Remuneration Act strictly is the most important fact. Even though strict enforcement will require a large administrative setup and consequently, huge administrative cost, gender injustice has to be removed.

Laws can be passed to punish the erring employers, and officials are to be appointed to see that equal wage is given to male and female laborers. The second alternative is to provide equality and creating awareness since village women are not only illiterate but also ignorant of their rights and privileges. Government and voluntary agencies can spread the message of the need for gene equality and creating legal awareness about the Equal Remuneration Act. Public media such as television, radio, magazines, and books can be used to remove this social injustice. The third alternative is to shift the excess supply of women laborers by starting women labor intensive agro-based industries in rural areas, and this will narrow down the wage differentials between genders. The fourth alternative is to execute effectively the existing women development programs such as Support to Training and Employment Programmes (STEP), Rashtriya Mahila Kosh (RMK) meeting the credit need of the women, and Mahila Yojana (IMY) (achievement of employment of women and bringing them into the mainstream). The fifth alternative is to organize agricultural trade union movements exclusively for women. This will certainly go a long way in narrowing sown the wage discrimination between male and female agricultural laborers.

Wage rates can also be increased by shifting the excess supply of labor from agriculture to 
areas where they could get employment. In other words, it is possible only through causing a scarcity in the supply of laborers in agriculture. Hence, the government can encourage entrepreneurs by providing subsidies and tax holidays to those who are starting small scale industries in rural areas. Special employment and anti-poverty programs like
Integrated Rural Development Programmes (IRDP), Training of Rural Youth for self-Employment (TRYSEM), Jawahar Rozar Yojana (JRY) can be further strengthened to increase employment and to eradicate poverty of the rural agricultural women laborers of Thanjavur district.

\section{Author Details}

Dr. R. Gopalasundar, Assistant Professor, PG Department and Research Centre in Economics, Saraswathi Narayanan College (A), Madurai, Tamilnadu, India, Email ID: gopal.sundar612@gmail.com. 